\title{
Examination of Test Anxiety and Cognitive Flexibility Levels of Students Preparing for the University Exam
}

\section{Research Article}

\section{Aysenur KULOGLU1, Fulya GORKEM ORHAN²}

${ }^{1}$ Firat University, Faculty of Education, Department of Education Programme, Elazı̆̆, Turkey, ORCID: 0000-0003-0217-8497

${ }^{2}$ Firat University, Faculty of Education, Department of Education Programme, Elazı̆̆, Turkey, ORCID: 0000-0002-1158-6508

To cite this article: Kuloglu, A., \& Gorkem-Orhan, F. (2021). Examination of test anxiety and cognitive flexibility levels of students preparing for the university exam, International Online Journal of Educational Sciences, 13(4), 996-1009.

\begin{tabular}{ll} 
ARTICLE INFO & ABSTRACT \\
\hline Article History: & The aim of this study was to investigate the relationship between test anxiety and cognitive flexibility \\
levels of students preparing for the university exam. 650 students studying in private training centers \\
in Malatya in 2019-2020 academic year participated in this study. Relational survey model was used \\
in this study. In data collection, "IDA Test Anxiety Scale" developed by Başol (2017) was used to \\
examine test anxiety and "Cognitive Flexibility Inventory" adapted to Turkish by Gülüm and Dağ \\
Available online: \\
(2012) was used to investigate cognitive flexibility levels. The IDA Test Anxiety Scale consists of two \\
sub-scales: Anxiety caused by Social Factors and Cognitive and Physiological Anxiety. Cognitive \\
flexibility inventory consists of two sub-scales: Alternatives and Control. The Cronbach alpha value \\
of the Test Anxiety Scale was .88. The Cronbach alpha value of the Cognitive Flexibility Inventory \\
was .87. The results of this study showed that the participants sometimes had "Anxiety caused by \\
Social Factors" and "Cognitive and Physiological Anxiety". It was found that female participants had \\
significantly higher test anxiety levels. The participants stated that they were neutral about the \\
statements in the Control sub-scale whereas they agreed with the statements in the Alternatives sub- \\
scale. There was no significant difference between the general cognitive flexibility level of the \\
participants and gender. It was found that there was a low and negative relationship between test \\
anxiety and cognitive flexibility levels of the participants. Based on the findings of this study, \\
suggestions were offered to decrease students' test anxiety levels and increase their cognitive \\
flexibility levels.
\end{tabular}

Keywords:

Test Anxiety, Cognitive Flexibility, Students preparing for university exam 


\section{Introduction}

Anxiety is the feeling that the individual will experience unpleasant events and having this feeling all the time (Biçer, 2015, p. 17). Individual's different mental, physical, intellectual behaviors when he or she faces with a situation he or she wants to avoid is regarded as state of anxiety (Semerci \& Özer, 2007, p. 11). Individuals experiencing anxiety are constantly having thoughts as if something bad will happen and they will face an uncomfortable situation. The individual can experience the state of anxiety in his/her dreams and can wake up in panic. The individual may not realize the grounds of anxiety (Uluşahin \& Öztürk, 2014, p. 452).

Individuals may feel as if an earthquake is happening in situations they are experiencing anxiety, which can even lead to loss of body balance. In addition, conditions such as color change in the skin and itching may be experienced (Kurt, 2006, pp. 20-21). The level of anxiety also influences the level of the individual's speech as the vibration of the vocal cords is also affected and thus individuals experience difficulties in establishing communication. During communication, they may swallow words, say the same words repetitively or use erroneous words (Cormier \& Hackney, 2013, p.139). Individuals set goals for their futures and thus they are required to take a number of exams to achieve them. While preparing for these exams, they may feel anxiety.

Exams are conducted to measure individuals' knowledge and levels. Individuals are required to take many exams before starting their professional life. Since exams will have a significant impact on the life of each individual in socio-economical terms, they lead to anxiety, fear and stress on people. Thus, individuals cannot reflect the knowledge they have in exams accurately (Semerci \& Özer, 2007, p. 24-25). Test anxiety takes place when individuals remove their past experiences from the consciousness level using their defense mechanisms, and when they experience a similar situation, they associate this situation with their past experience. In this sense, an unsuccessful exam in the past may cause anxiety in future exams (Kurt, 2006, p.15).

Thinking about exams can lead to anxiety when it affects the lives and emotions of individuals. If thinking about exam negatively affects people's mood, makes them nervous and affects their lives in a way that makes them feel uneasy, it leads to anxiety. The changes in emotional state and psychological effects experienced by an individual before the exam disrupt his/her daily routine and life order. In this context, spiritual gaps in their feelings can also be observed (Semerci \& Özer, 2007, p.23). Students preparing for the university exam may experience test anxiety and, in this period, conflict become a process that exhausts students emotionally. Test anxiety is the state of anxiety experienced by individuals during and after the period in which they prepare for the exam. It refers to the situation that the individual cannot use the information and knowledge he or she has in the exam (Biçer, 2015, p. 18). Individuals suffering from test anxiety may think, during the exam, that they are more unsuccessful than everyone, they may feel uncertain about their IQ level and overexcited, they may not feel comfortable in their body, they may be uneasy, they may forget the knowledge they have learned and they may think intensely about their future (Semerci \& Özer, 2007, p. 72-76).

While preparing for the exam, students seek solutions when they are confronted with problems and cognitively use their thoughts in the solution process. Cognitive flexibility refers to our ability to produce solutions when we are faced with a problem. The level of cognitive flexibility plays an important role in individuals' communication with other individuals. Individuals having higher cognitive flexibility presents favorable attitudes in their communication with others (Bilgin, 2009a, p. 145). Cognitive flexibility facilitates individuals to have a positive perspective on situations, in that, they produce numerous options instead of making a single choice in their lives. They also do not deal their choices with stress or hopelessness, on the contrary, they act in a confident and positive way. Cognitive flexibility enhances constructive communication in interpersonal relationships. It provides a broader perspective rather than dealing with situations in a 
negative way (Dalkılıç, 2017, p. 215). In order to have cognitive flexibility, individuals need to be knowledgeable in their field and as a result their success in solving problems increases and becomes flexible. In addition, if an individual think through the job assigned to him or her cognitively flexible in spite of several obstacles, he or she will deal with the job in detail (Sinnott, Hilton, Wood, \& Douglas, 2020, p. 4).

Cognitive flexibility takes place as a result of the interaction of cognitive processes. When a figure is shown to individuals, they treat it with different perspectives and each grasps a different meaning. The flexibility skills of individuals are important in adapting to new situations since individuals change their perceptions on the basis of their flexibility. Cognitive flexibility is directly related to our language ability. Language ability is the basic tool for social interaction (Deák, 2003, pp. 272-275). Individuals thinking cognitively flexible try to come up with alternatives and seek new ways in line with the new situation in circumstances they have not experienced before in their daily routine, and try to produce more than one solution in such situations. It can be said that being productive is closely linked to cognitive flexibility (Çuhadaroğlu, 2011, p. 15).

Students may confront with more than one problem while preparing for the exam, and these problems may lead to anxiety. Problem solving skills can reduce individuals' anxiety. As individuals find solutions to the problems they face, their anxiety decreases and their problem-solving skills increase. Cognitive flexibility is related to individuals' problem-solving skills. It is thought that test anxiety and cognitive flexibility may have a significant role in this context. The aim of this study was to investigate the relationship between test anxiety and cognitive flexibility of students preparing for the university exam.

\section{Method}

The quantitative research design was used in this study the aim of which was to examine the relationship between test anxiety and cognitive flexibility of students preparing for the university exam. In addition, relational survey model was adopted in the study. Relational survey is used to explain the connection between more than one variable and correlation is applied to interpret the relationship Karaca, Yurdabakan, Çetin, Nartgün, \& Kapaksiz, 2010, p. 282). The relationship between test anxiety and cognitive flexibility was investigated in the present study.

\section{Population and Sample}

The population of this study consisted of students between 18-23 years old who were attending the university exam preparation institutions in Malatya province in 2019-2020. Non-random convenience sampling was used to select the participants. Convenience sampling is the sampling method that is easily accessible, saves time and contributes to reaching more participants (Büyüköztürk, Çakmak, Akgün, Karadeniz, \& Demirel, 2015, p. 92). As a result, a total of 650 students, 371 females and 279 males, preparing for the university exam in Malatya took part in the present study.

\section{Data Collection Tools}

\section{IDA Test Anxiety Scale}

The "IDA Test Anxiety Scale" developed by Başol (2017) was used to collect data on test anxiety. It consists of a total of 15 items and is a 5-point Likert-type scale. Items 5 and 15 are reverse scored. The highest test score that can be obtained from the scale is 75 . The total score less than 45 points indicates low test anxiety, score between 45-60 points indicates moderate test anxiety, and score above 60 points indicates the high level of test anxiety (Başol, 2017). The scale consists of two sub-scales: cognitive and physiological anxiety and anxiety caused by social factors. The Cognitive and Physiological Anxiety sub-scale consists of items 1, 2, 4, 6 , $8,9,11,12,14$. A score below 27 in this sub-scale means that there is no anxiety. The Anxiety caused by Social Factors sub-scale consists of items 3, 5, 7, 10, 13, 15. A score below 18 indicates no anxiety in this sub-scale 
(Başol, 2017). The Cronbach Alpha coefficients of the scale are 89 for the Cognitive and Physiological Anxiety sub-scale, .70 for Anxiety caused by Social Factors sub-scale, and .86 for the total scale (Başol, 2017). The reliability analysis of the scale showed that it had Cronbach's alpha value of .885 . The Cronbach's alpha value on the basis of factors is .898 for Factor 1 and .618 for Factor 2. KMO value of the scale was calculated as .938 and the Bartlett's test as $4522,466 \mathrm{p}=.000$ in this study. It is a five-point Likert-type scale for each item and one of the options "never", "rarely", "sometimes", "often" and "always" is marked. Scores from 1 to 5 are given.

\section{The Cognitive Flexibility Inventory}

Cognitive Flexibility Inventory developed by Dennis and Wal and adapted into Turkish by Gülüm and Dağ (2012) was used to collect data on cognitive flexibility. The scale, which consists of 20 items, is developed in order to measure individuals' ability to produce alternative, coordinated, appropriate and balanced thoughts in difficult situations. Higher scores obtained from the inventory indicates higher cognitive flexibility. It consists of two sub-scales as alternatives and control. Items 2, 4, 7, 9, 11 and 17 are reverse scored. Items 2, 4, 7, 9, 11, 15 and 17 are included in the control sub-scale. All other items are involved in the alternatives sub-scales. The Cronbach's alpha value in the adaptation study of the scale was .81 (Gülüm \& Dağ, 2012). The reliability analysis showed that the Cronbach alpha value of the inventory was .87. Cronbach's alpha value on the basis of factors is .799 for Factor 1 and .886 for Factor 2. KMO value of the scale was calculated as .922 and the Bartlett's test as 4450,057 p= .000 in this study. It is a five-point Likert-type scale and one of the options "strongly disagree", "somewhat disagree", "neutral", "agree" and "strongly agree" is marked. Scores from 1 to 5 are given.

\section{Data Analysis}

SPSS 22.0 package program was used in data analysis. The percentages and frequencies for the gender of the participants were determined. The means and standard deviations of the Likert type items were calculated to determine the test anxiety and cognitive flexibility levels of the participants.

Prior to the analyses, the kurtosis and skewness coefficients were investigated in order to determine whether the scores were normally distributed. IDA Test Anxiety Scale had a total kurtosis value of -.754 and a skewness value of -.133. The kurtosis value of the Cognitive Flexibility Inventory was .399 and the skewness value was -.343 . The kurtosis and skewness values between +1 and -1 indicate that the data is normally distributed (Büyüköztürk, 2016, p. 40).

The "t-test" was performed in order to determine whether there was a significant difference between the test anxiety and cognitive flexibility levels of the participants in terms of gender. When a significant difference was found, the means were compared. The t-test reveals the significance of the difference between the means of two unrelated samples (Büyüköztürk, 2016, p. 39).

Pearson product-moment correlation coefficient $(r)$ analysis was applied to reveal the relationship between test anxiety levels and cognitive flexibility levels of the participants. The Pearson Correlation Coefficient determines whether there is a relationship between two continuous and normally distributed variables. The correlation coefficient takes a value between +1 and -1 . A negative value indicates a negative relationship and a positive value means a positive relationship. The relationship gets stronger as it approaches -1 or $+1.0 .00-0.30$ indicates low correlation, 0.30-0.70 moderate correlation, and 0.70-1.00 high correlation. The statistical significance level was $\mathrm{p}<0.05$. P value less than 0.05 indicates statistically significant whereas $\mathrm{p}$ value greater than 0.05 means that it is not statistically significant (Büyüköztürk, Çokluk, \& Köklü, 2013, p. 144).

\section{Findings}

This section presents the results of the analysis performed to investigate the test anxiety and cognitive flexibility of the participants, and the level of significance between them. 
Table 1. Participants' opinions on "Cognitive and Physiological Anxiety" sub-scale

\begin{tabular}{|c|c|c|c|c|}
\hline Item & Statements & n & $\overline{\boldsymbol{X}}$ & sd \\
\hline 1 & As the exam gets closer, I get excited or worried if I confuse what I know. & 650 & 3.41 & 1.30 \\
\hline 2 & $\begin{array}{l}\text { As the exam gets closer, thoughts such as if I slide the answers out, if I confuse what I know } \\
\text { because of anxiety, occupy my mind. }\end{array}$ & 650 & 2.86 & 1.44 \\
\hline 4 & $\begin{array}{l}\text { As the exam gets closer, my delusions such as I wish I had studied harder, I wish I had prepared } \\
\text { differently, or what if fail, increase. }\end{array}$ & 650 & 3.51 & 1.30 \\
\hline 6 & $\begin{array}{l}\text { As the exam day gets closer, my concerns about the exam increase as the number of } \\
\text { topics/questions I cannot solve increases. }\end{array}$ & 650 & 3.62 & 1.25 \\
\hline 8 & $\begin{array}{l}\text { During the exam, I experience physiological problems (such as accelerated heartbeat, headache, } \\
\text { cold hands, sweating, etc.). }\end{array}$ & 650 & 2.74 & 1.45 \\
\hline 9 & I cannot convince myself that I am ready on the exam day, even though I studied hard before. & 650 & 2.94 & 1.42 \\
\hline 11 & $\begin{array}{l}\text { Being physically exhausted in the exam (not being able to sleep due to stress, being tired, } \\
\text { exhausted, nervous) damage my morale on the exam day. }\end{array}$ & 650 & 3.22 & 1.41 \\
\hline 12 & The concern that I will fail puts a lot of pressure on me on the exam day. & 650 & 3.25 & 1.40 \\
\hline 14 & As the exam gets closer, my anxiety increases as I cannot think of anything else. & 650 & 3.30 & 1.36 \\
\hline \multicolumn{2}{|c|}{ The cognitive and physiological sub-scale } & 650 & 3.20 & 1.02 \\
\hline
\end{tabular}

The means and standard deviations in the Cognitive and Physiological Anxiety sub-scale in Table 1 showed that the first three items with the highest mean score are as follows: Item 6 "As the exam day gets closer, my concerns about the exam increase as the number of topics/questions I cannot solve increases." (=3.62), Item 4 "As the exam gets closer, my delusions such as I wish I had studied harder, I wish I had prepared differently, or what if fail, increase." (=3.51), and Item 1 "As the exam gets closer, I get excited or worried if I confuse what I know." (=3.41), respectively.

Table 2. Participants' opinions on "Anxiety Based on Family and Environment"

\begin{tabular}{|c|c|c|c|c|}
\hline Item & Statements & $\mathbf{n}$ & $\overline{\boldsymbol{X}}$ & sd \\
\hline 3 & $\begin{array}{l}\text { Worries such as what will be the reaction of the people around me if I get a bad result in } \\
\text { the exam occupy my mind. }\end{array}$ & 650 & 3.52 & 1.36 \\
\hline 5 & $\begin{array}{l}\text { I do not worry about what my family will say (reproaching, getting angry, comparing, } \\
\text { blaming, accusing) if I have a bad exam. }\end{array}$ & 650 & 3.27 & 1.42 \\
\hline 7 & $\begin{array}{l}\text { The thought that if I get a bad result in the exam, I will become worthless in the eyes of } \\
\text { the people I love, exhausts me. }\end{array}$ & 650 & 2.69 & 1.53 \\
\hline 10 & $\begin{array}{l}\text { Thinking about what will happen if I fail (upsetting the family, making no progress while } \\
\text { others are leading their lives, falling behind) occupies my mind. }\end{array}$ & 650 & 3.55 & 1.37 \\
\hline 13 & $\begin{array}{l}\text { I do not even want to think about the reactions I will get from the environment If I fail } \\
\text { the exam,. }\end{array}$ & 650 & 3.20 & 1.53 \\
\hline 15 & My success or failure in the exam means little to my family and friends. & 650 & 4.08 & 1.24 \\
\hline \multicolumn{2}{|c|}{ Anxiety caused by Social Factors sub-scale } & 650 & 3.38 & .83 \\
\hline
\end{tabular}

The means and standard deviations in the Anxiety caused by Social Factors sub-scale in Table 2 indicated that the first three items with the highest mean score are as follows: Item 15 "My success or failure in the exam means little to my family and friends." (=4.08), Item 10 "Thinking about what will happen if I fail (upsetting the family, making no progress while others are leading their lives, falling behind) occupies my mind." (=3.55) and Item 3 "Worries such as what will be the reaction of the people around me if I get a bad result in the exam occupy my mind." (=3.52), respectively.

The t-test results regarding whether the participants' test anxiety differs by gender are presented in Table 3. 
Table 3. T-Test results of the Participants' Test Anxiety in terms of Gender

\begin{tabular}{|c|c|c|c|c|c|c|c|}
\hline Scale & Gender & $\mathbf{n}$ & $\bar{x}$ & sd & sd & $\mathbf{t}$ & $\mathrm{p}$ \\
\hline \multirow[t]{2}{*}{ The Cognitive and Physiological } & Female & 371 & 31.32 & 8.40 & 648 & 8.175 & $0,000^{*}$ \\
\hline & Male & 279 & 25.64 & 9.24 & & & \\
\hline \multirow[t]{2}{*}{ Anxiety caused by Social Factors } & Female & 371 & 21.19 & 4.81 & 648 & 5.131 & $0,000^{*}$ \\
\hline & Male & 279 & 19.20 & 5.00 & & & \\
\hline \multirow[t]{2}{*}{ Test Anxiety } & Female & 371 & 52.52 & 11.84 & 648 & 7.814 & $0,000^{*}$ \\
\hline & Male & 279 & 44.84 & 13.10 & & & \\
\hline
\end{tabular}

As shown in Table 3, the examination of Cognitive and Physiological Anxiety sub-scale of the participants in terms of gender revealed a significant difference [ $t(648)=8.175 ; \mathrm{p}<.05]$. It was also found that the female participants' average score of cognitive and physiological anxiety $(=31.32)$ was higher than that of male participants $(=25.64)$.

Similarly, the examination of Anxiety caused by Social Factors sub-scale in terms of gender showed a significant difference $[\mathrm{t}(648)=5.131 ; \mathrm{p}<.05]$. It was found that female participants' average score of the anxiety sub-dimension $(=21.19)$ was higher than that of the male participants $(=19.20)$. Both male and female participants had anxiety caused by social factors.

Finally, the result of test anxiety levels with regard to gender indicared a significant difference $[\mathrm{t}(648)=$ 7.814; $\mathrm{p}=0.000 \mathrm{p}<.05]$. It was found that female participants' average test anxiety scores $(=52.52)$ were higher than those of male participants $(=44.84)$.

The Cognitive Flexibility Inventory results of the participants are presented below. First of all, statistical tests appropriate for the variables were performed and then result were presented in tables.

Table 4. Participant's opinions on the "Control" Sub-scale

\begin{tabular}{lllll}
\hline Item & Statements & $\mathbf{n}$ & $\overline{\boldsymbol{X}}$ & $\mathbf{s d}$ \\
\hline $\mathbf{2}$ & I have a hard time making decisions when faced with difficult situations. & 650 & 3.19 & 1.28 \\
\hline $\mathbf{4}$ & When I encounter difficult situations, I feel like I am losing control. & 650 & 3.18 & 1.40 \\
\hline $\mathbf{7}$ & $\begin{array}{l}\text { When encountering difficult situations, I become so stressed that I cannot think of a way to } \\
\text { resolve the situation. }\end{array}$ & 650 & 3.54 & 1.33 \\
& find it troublesome that there are so many different ways to deal with difficult situations & 650 & 3.13 & 1.36 \\
\hline $\mathbf{9}$ & When I encounter difficult situations, I just don't know what to do. & 650 & 3.58 & 1.30 \\
\hline $\mathbf{1 1}$ & I am capable of overcoming the difficulties in life that I face. & 650 & 3.79 & 1.06 \\
\hline $\mathbf{1 5}$ & I feel I have no power to change things in difficult Situation. & 650 & 3.36 & 1.32 \\
\hline $\mathbf{1 7}$ & Control Sub-scale & 650 & 3.40 & .87 \\
\hline
\end{tabular}

The means and standard deviations in the Control sub-scale of the Cognitive Flexibility Inventory in Table 2 showed that the first three items with the highest mean score are as follows: Item 15 "I am capable of overcoming the difficulties in life that I face." (=3.79), Item 11 "When I encounter difficult situations, I just don't know what to do." (=3.58) and Item 7 "When encountering difficult situations, I become so stressed that I cannot think of a way to resolve the situation." (=3.54), respectively.

Table 5. Participant's opinions on the "Alternatives" Sub-scale

\begin{tabular}{lllll}
\hline Item & Statements & $\mathbf{n}$ & $\overline{\boldsymbol{X}}$ & $\mathbf{s d}$ \\
\hline $\mathbf{1}$ & I am good at "sizing up" situations. & 650 & 3.80 & 1.05 \\
\hline $\mathbf{3}$ & I consider multiple options before making a decision. & 650 & 3.99 & 1.12 \\
\hline $\mathbf{5}$ & I like to look at difficult situations from many different angles. & 650 & 3.81 & 1.17 \\
\hline $\mathbf{6}$ & I seek additional information not immediately available before attributing causes to behavior. & 650 & 3.64 & 1.18 \\
\hline $\mathbf{8}$ & I try to think about things from another person's point of view. & 650 & 3.67 & 1.24 \\
\hline $\mathbf{1 0}$ & I am good at putting myself in others' shoes. & 650 & 3.73 & 1.27
\end{tabular}




\begin{tabular}{|c|c|c|c|c|}
\hline 12 & It is important to look at difficult situations from many angles. & 650 & 4.12 & 1.11 \\
\hline 13 & When in difficult situations, I consider multiple options before deciding how to behave.. & 650 & 3.91 & 1.10 \\
\hline 14 & I often look at a situation from different viewpoints. & 650 & 3.92 & 1.08 \\
\hline 16 & I consider all the available facts and information when attributing causes to behavior. & 650 & 3.90 & 1.06 \\
\hline 18 & When I encounter difficult situations, I stop and try to think of several ways to resolve it. & 650 & 3.85 & 1.12 \\
\hline 19 & I can think of more than one way to resolve a difficult situation I'm confronted with. & 650 & 3.71 & 1.04 \\
\hline 20 & I consider multiple options before responding to difficult situations. & 650 & 3.82 & 1.18 \\
\hline \multicolumn{2}{|c|}{ Alternatives Sub-scale } & 650 & 3.84 & .739 \\
\hline
\end{tabular}

The means and standard deviations in the Alternatives sub-scale of the Cognitive Flexibility Inventory in Table 2 revealed that the first three items with the highest mean score are as follows: Item 12 "It is important to look at difficult situations from many angles." (=4.12), Item 3 "I consider multiple options before making a decision." (=3.99) and Item 14 "I often look at a situation from different viewpoints." (=3.92), respectively.

The t-test results regarding whether the participants' cognitive flexibility differs by gender are presented in Table 6.

Tablo 6. T-Test results of the Participants' Cognitive Flexibility in terms of Gender

\begin{tabular}{|c|c|c|c|c|c|c|c|}
\hline Scale & Gender & $\mathbf{n}$ & $\bar{X}$ & sd & sd & $\mathbf{t}$ & $\mathrm{p}$ \\
\hline \multirow{2}{*}{ Control } & Female & 371 & 23.07 & 5.91 & \multirow[t]{2}{*}{648} & \multirow[t]{2}{*}{-3.529} & \multirow[t]{2}{*}{$0,000^{*}$} \\
\hline & Male & 279 & 24.77 & 6.29 & & & \\
\hline \multirow[b]{2}{*}{ Alternatives } & Female & 371 & 50.10 & 9.42 & \multirow[t]{2}{*}{648} & \multirow[t]{2}{*}{.520} & \multirow[t]{2}{*}{0,603} \\
\hline & Male & 279 & 49.70 & 9.87 & & & \\
\hline \multirow{2}{*}{ Cognitive Flexibility } & Female & 371 & 73.17 & 12.48 & \multirow[t]{2}{*}{648} & \multirow[t]{2}{*}{-1.279} & \multirow[t]{2}{*}{0,201} \\
\hline & Male & 279 & 74.47 & 13.37 & & & \\
\hline
\end{tabular}

${ }^{*} \mathrm{p}<0,05$

As is seen in Table 3, the examination of Control sub-scale of the participants in terms of gender revealed a significant difference $[\mathrm{t}(648)=-3.529 ; \mathrm{p}=0.000 \mathrm{p}<.05]$. It was also found that the male participants' average score in Control sub-scale $\left(X_{\odot}=24.77\right)$ was higher than that of female participants $\left(X_{\odot=23.07)}\right.$.

However, the examination of Alternatives sub-scale in terms of gender did not indicate a significant difference [ $\mathrm{t}(648)=.520 ; \mathrm{p}=0.603>0.05]$. It was found that that the cognitive flexibility score of female students was higher than that of male students.

Similarly, the result of cognitive flexibility level of the participants with regard to gender did not reveal a significant difference [ $\mathrm{t}(648)=-1.279 ; \mathrm{p}=0.201>0.05]$. The examination of cognitive flexibility levels also showed that both female participants $\left(X_{\odot=73.17)}\right.$ male participants $\left(X_{\odot}=74.47\right)$ had a higher level of cognitive flexibility. Finally, it was found that male participants had higher cognitive flexibility scores than female participants.

The results of the Correlation Analysis performed to investigate the relationship between Test Anxiety and Cognitive Flexibility of the participants are presented in Table 7. 
Tablo 7. Correlation Analysis Results of the Relationship Between Test Anxiety and Cognitive Flexibility of the Participants

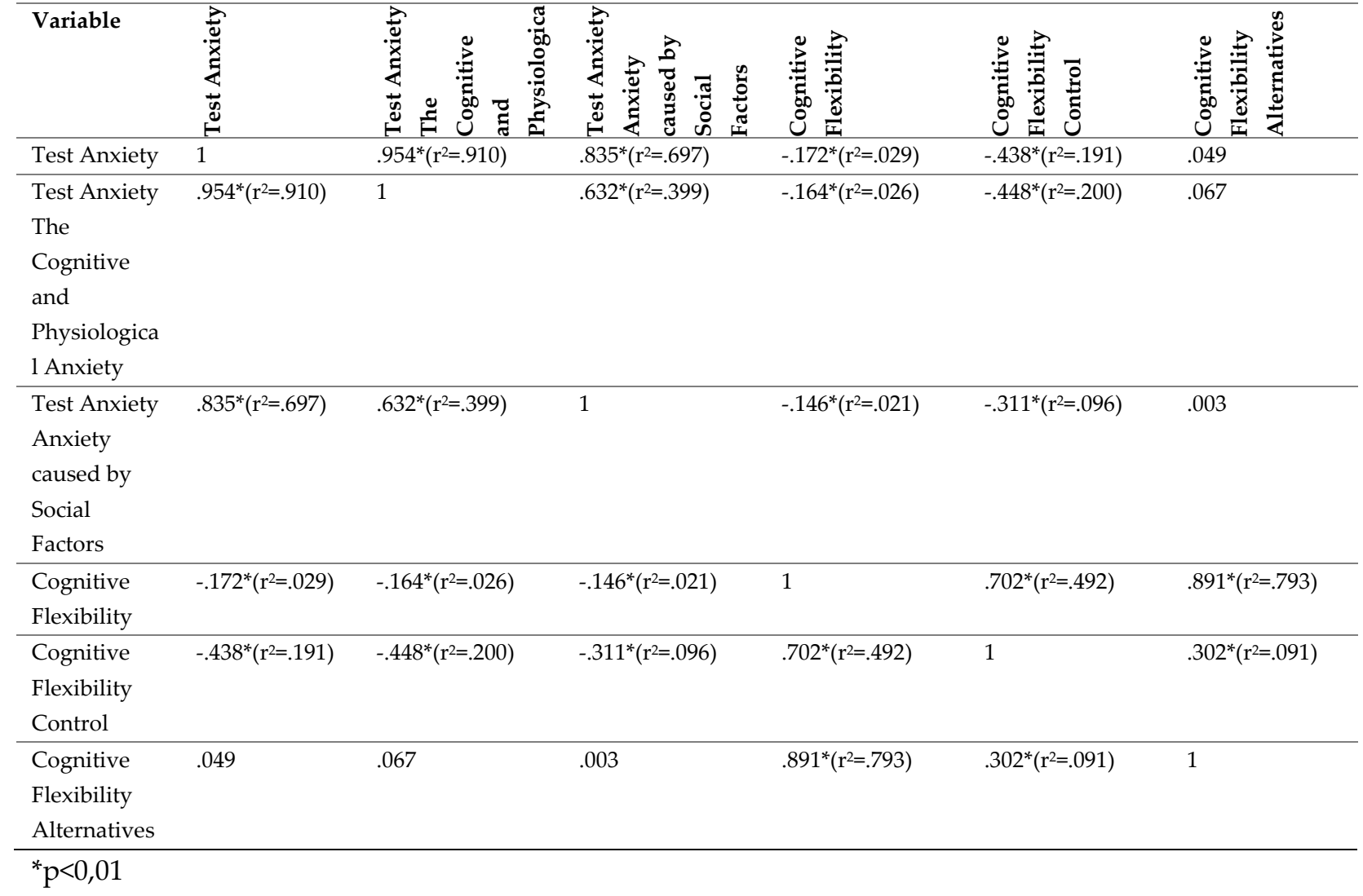

With regard to the sub-problem of the present study, "What is the relationship between test anxiety and cognitive flexibility levels of students preparing for the university exam?", correlation coefficients were calculated in order to find out whether there was a relationship between test anxiety and cognitive flexibility of the participants." Table 7 revealed a statistical relationship between test anxiety and cognitive flexibility of the participants.

The results showed that there was a low, negative and significant relationship between test anxiety and cognitive flexibility of the participants $(\mathrm{r}=-.172 ; \mathrm{p}<0.01)$. The participants' test anxiety levels increased, as their cognitive flexibility levels decreased.

A moderate, negative and significant relationship was found between the test anxiety and the control sub-scale of Cognitive Flexibility Inventory $(\mathrm{r}=-.438 ; \mathrm{p}<0.01)$. It was found that the cognitive flexibility control levels of the participants decreased with the increase in their test anxiety levels.

A significant relationship was not found between the test anxiety and the Alternatives sub-scale of Cognitive Flexibility Inventory.

In addition, a low, negative and significant relationship was found between Cognitive and Physiological Anxiety sub-scale of IDA Test Anxiety Scale, and cognitive flexibility of the participants $(r=-.164 ; p<0.01)$. It was revealed that the cognitive flexibility levels of the participants decreased as their cognitive and physiological anxiety levels increased.

A moderate, negative and significant relationship was found between Cognitive and Physiological Anxiety sub-scale of IDA Test Anxiety Scale and Control sub-scale of Cognitive Flexibility Inventory ( $\mathrm{r}=-.448$; $\mathrm{p}<0.01)$. It was revealed that the highest relationship was between Cognitive and Physiological Anxiety and Control sub-scale of Cognitive Flexibility Inventory. In other words, as cognitive and physiological anxiety increased, cognitive flexibility control levels decreased. 
A low, negative and significant relationship was found between Anxiety caused by Social Factors subscale of IDA Test Anxiety Scale and cognitive flexibility of the participants $(r=-.146 ; p<0.01)$. The participants' anxiety levels caused by social factor increased with the decrease in their cognitive flexibility levels.

Finally, a moderate, negative and significant relationship was found between Anxiety caused by Social Factors sub-scale of IDA Test Anxiety Scale and Control sub-scale of Cognitive Flexibility Inventory ( $\mathrm{r}=-.311$; $\mathrm{p}<0.01)$. In other words, cognitive and physiological anxiety increased, cognitive flexibility control levels decreased.

\section{Discussion, Conclusion and Suggestions}

The aim of this research was to investigate the test anxiety and cognitive flexibility levels of students preparing for the university exam, and to examine their relationship.

The findings of the present study showed that the participants had a moderate level of test anxiety. There was a significant difference between test anxiety level, Cognitive and Physiological Anxiety sub-scale, Anxiety caused by Social Factors sub-scale with regard to gender in favor of female participants.

This finding of the present study is in consistence with the findings of Atak (2004), Alammari and Bukhary (2019), Bacanlı and Driver (2006), Boztepe (2016), Bilir (2019), Dalkıran (2012), Smoke (2008), Gençdoğan (2010), Güler and Çakır (2013), Hanımoğlu (2010), Mohammadyari (2012), Onuk (2017), Kilit (2019), Lakot (2019), Pazarlı (2009), Putwain (2007), Softa, Karaahmetoğlu and Çabuk (2015), Serim (2016), Şahinler (2018), Ürgüp (2017), Yalçınkaya (2011), Yolcu (2014), and Yusefzadeh, Iranagh and Nabilou (2019). However, the findings of Boyacioğlu (2010), Bozkurt (2012), Kurt (2017) and Ün (2018) do not support the findings of the present study. The possible reason for this difference may be that the cities and cultures of the students are different and their perspectives on the exam differ. In addition, the findings of Atak (2004), Ün (2018) and Yolcu (2014) differ from the results of the present study with regard to Anxiety caused by Social Factors sub-scale. The possible explanation of this difference may be the difference in the examination system and the time when the studies were carried out.

The present study showed that the general cognitive flexibility scores of the participants had higher cognitive flexibility levels. The studies of Gürbüz (2017), Bozkurt (2019), Kardeş (2016) and Zahal (2014) supports this finding. The possible reason for this finding may be that individuals gain experience through preparing for the exam and experiencing many problems.

The examination of cognitive flexibility level of the participants in terms of gender revealed no significant difference. The examination Control sub-scale in Cognitive Flexibility Inventory with regard to gender showed a significant difference and that the cognitive flexibility levels of male participants were higher than their female counterparts. The studies of Asici and Twin (2015), Bozkurt (2019), Çelikkaleli (2014), Farmer (2019), Çuhadaroğlu (2011), Gürbüz (2017), Kardeş (2016), Kurt (2019), Özcan (2016), Sinnott, Hilton, Wood and Douglas (2020), Tutuş (2019), Zahal (2014) are consistent with this finding of the present study. However, the studies of Oral and Kolburan (2019) and Yavuz (2019) are in contrast with this finding. It can be thought that there may be a difference in the result of the study due to the fact that the research group of the study consisted of students and the other study consisted of adults, and the average age was higher than our study. The reason for this difference may be that the sample of the present study consisted of students while adults took part in other studies, and that the average age in these studies was higher than the present study. Zahal (2014) and Çiftçi (2019) stated in their studies that there was not a significant difference between gender and Control sub-scale, which does not support the result of the present study. A possible explanation for this difference may be the difference of the region where the students live and cultural differences. In addition, it may be put forward that women are more emotional and they have more detailed perspectives on situations than men. 
A low, negative and significant relationship was found between test anxiety and cognitive flexibility of the participants. In other words, test anxiety increased as cognitive flexibility levels decreased. A possible reason for this situation may be that individuals having test anxiety may have a negative perception on problems and may experience more anxiety and hopelessness due to the difficulties they are confronted with. If an individual is looking for ways to cope with a situation in which he or she will be harmed and believes that he or she will deal with it, his or her anxiety will begin to decrease. In contrast, if an individual does not believe in himself or herself and does not believe that he or she will cope with the situation and if this situation leads to more harm to the individual, his or her anxiety increases (Beck, 2005, p. 65). On the other hand, individuals who do not have cognitive flexibility exaggerate the problems and make them more problematic instead of solving them, as well as questioning why they are confronted with these problems (Bedel \& Ulubey, 2015, p. 298). Bozkurt (2019) stated in her study that there was no relationship between test anxiety and cognitive flexibility levels of the students. A possible reason for this situation may be that the environment in which the student group lives and the difficulties they face are different and thus the anxiety they have during the exam may differ.

Future studies should address the following issues:

- The sample of the present study consisted of students preparing for the university exam in Malatya. Therefore, similar studies can be carried out with students preparing for different exams and different research groups.

- Students living in different provinces can take part in future studies.

- The present study was a quantitative study. A qualitative study can be carried out in order to investigate the reasons for the student's test anxiety and the factors that lead to the development of cognitive flexibility. 


\section{REFERENCES}

Alammari, M. R. and Bukhary, D. M. (2019). Factors Contributing to Prosthodontic Exam Anxiety in Undergraduate Dental Students. Advances in Medical Education and Practice, 10, 31.

Asıcı, E. ve İkiz, F. (2015). Mutluluğa Giden Bir Yol: Bilişsel esneklik. Mehmet Akif Ersoy Üniversitesi Eğitim Fakültesi Dergisi, 1(35), 191-211.

Atak, M. (2004). Genel Lise Öğrencilerinin Sınav Kaygısı ile Ailenin Sosyo-Ekonomik Düzeyi Arasındaki İlişkinin İncelenmesi (Kayseri Örneği). Yayımlanmamış Yüksek Lisans Tezi. Kayseri: Erciyes Üniversitesi, Sosyal Bilimler Enstitüsü.

Bacanlı, F. ve Sürücü. M. (2006). İlköğretim 8. Sınıf Öğrencilerinin Sınav Kaygıları ve Karar Verme Stilleri Arasındaki İlişkilerin İncelenmesi. Kuram ve Uygulamada Eğitim ve Yönetimi Dergisi, 45(45), 7-35.

Başol, G. (2017). Ayda Sınav Kaygısı Ölçeği: Geçerlik ve Güvenirlik Çalışması. Uluslararası Ĕ̆itim Bilimleri Dergisi, 4 (13), 173-193.

Beck, T. A. (2005). Bilişsel Terapi ve Duygusal Bozukluklar (Çev. A. Türkcan.). İstanbul, Litera Yayıncılık.

Bedel, A. ve Ulubey, E. (2015). Ergenlerde Başa Çıkma Stratejilerini Açılamada Bilişsel Esnekliğin Rolü. Elektronik Sosyal Bilimler Dergisi, 14 (55), 291-300.

Biçer, U. (2015). Sınav Kaygısını Yenmek İçin 16 Etkin Uygulama. İstanbul, Cinius Yayınları.

Bilir, A. (2019). Üniversite Sınavına Hazırlanan Öğrencilerde Ana-Baba Tutumu ile Sınav Kaygısı Arasındaki İlişki: Adana İli Örneği. Yayımlanmamış Yüksek Lisans Tezi. Mersin: Çağ Üniversitesi, Sosyal Bilimler Enstitüsü.

Bilgin, M. , (2009a), Bilişsel Esnekliği Yordayan Bazı Değişkenler, Çukurova Üniversitesi Eğitim Fakültesi Dergisi, 36 (3), 142-157.

Boyacıoğlu, N. E. (2010). Ergenlerde Mantık Dışı İnançlar ve Sınav Kayg̊ısı. Yayımlanmamış Yüksek Lisans Tezi. İstanbul: İstanbul Üniversitesi, Sağlık Bilimleri Enstitüsü.

Bozkurt, N. (2019). Ergenlerde Psikolojik Sağlamlık ve Bilişsel Esneklik Düzeylerinin Sınav Kaygısı ile İlişkisi. Yayımlanmamış Yüksek Lisans Tezi. İstanbul: İstanbul Üniversitesi, Cerrahpaşa Lisansüstü Eğitim Enstitüsü.

Bozkurt, S. (2012). İlköğretim İkinci Kademe Öğrencilerinde Sınav Kaygısı, Matematik Kaygısı, Genel Başarı ve Matematik Başarısı Arasındaki İlişkilerin İncelenmesi. Yayımlanmamış Yüksek Lisans Tezi. İstanbul: İstanbul Üniversitesi, Sosyal Bilimler Enstitüsü.

Boztepe, D. (2016). Ebeveyn Beklentilerinin Sınav Kaygısı Üzerindeki Etkisi: Lise Son Sını Öğrencilerine Yönelik Bir Değerlendirme. Yayımlanmamış Yüksek Lisans Tezi. İstanbul: Aydın Üniversitesi, Sosyal Bilimler Enstitüsü.

Büyüköztürk, Ş. (2016). Sosyal Bilimler İçin Veri Analizi El Kitabı. 22. Baskı. Ankara, Pegem Akademi Yayıncılık.

Büyüköztürk, Ş. , Çakmak, K. E. , Akgün, E. Ö. , Karadeniz, Ş.ve Demirel, F. (2015). Bilimsel Araştırma Yöntemleri. 19. Baskı. Ankara, Pegem Akademi Yayıncılık.

Büyüköztürk, Ş. Çokluk, Ö ve Köklü, N. (2013). Sosyal Bilimler İçin İstatistik.13. Baskı. Ankara, Pegem Akademi Yayıncilik.

Cormier, S. ve Hackney, H. (2013). Psikolojik Danışma Stratejiler ve Müdahaleler (Çev. Ed. S. Doğan ve B. Yaka). Ankara, Pegem Akademi Yayıncilı. 
Çelikkaleli, Ö. (2014). Ergenlerde Bilişsel Esneklik ile Akademik, Sosyal ve Duygusal Yetkinlik İnançları Arasındaki İlişki. Eğitim ve Bilim, 39 (176), 347-354.

Çiftçi, C. M. (2019). Üniversite Öğrencilerinin, Yetişkin Ayrılma Anksiyetesi ve Bilişsel Esneklik Düzeyleri ile Sosyal Anksiyete Düzeyleri Arasındaki İlişkinin İncelenmesi. Yayımlanmamış Yüksek Lisans Tezi. İstanbul: Gelişim Üniversitesi, Sosyal Bilimler Enstitüsü.

Çuhadaroğlu, A. (2011). Bilişsel Esnekliğin Yordayıııları. Yayımlanmamış Doktora Tezi. Ankara: Ankara Üniversitesi, Eğitim Bilimleri Enstitüsü.

Dalkılıç, M. (2017). The Effect of Cognitıve Flexıbılıty of Athletes on Person-Organızatıon. European Journal of Physical Education and Sport Science, 5 (3), 213-224.

Dalkıran, 0. (2012). Dershane Öğrencilerinin Fiziksel Aktivitede Bulunma Değişkenine Göre Sürekli Kaygı, Sınav Kaygısı ve Sosyal Beceri Düzeyleri ile Sınav Performanslarının Değerlendirilmesi. Yayımlanmamış Yüksek Lisans Tezi. Ankara: Ankara Üniversitesi, Sağlık Bilimleri Enstitüsü.

Dennis, J. P., and Vander Wal, J. S. (2010). The Cognitive Flexibility Inventory: Instrument Development and Estimates of Reliability and Validity. Cognitive Therapy and Research, 34, 241-253.

Deák, G. O. (2003). The Development of Cognitive Flexibility and Language Abilities. Advances in Child Development and Behavior, 31, 271-327.

Duman, G.K. (2008). İlköğretim 8. SinıfÖğrencilerinin Durumluk Sürekli Kaygı Düzeyleri İle Sınav Kaygısı Düzeyleri ve Ana - Baba Tutumları Arasındaki İlişkinin İncelenmesi. Yayımlanmamış Yüksek Lisans Tezi. İzmir: Dokuz Eylül Üniversitesi, Eğitim Bilimleri Enstitüsü.

Gençdoğan, B. (2010). Lise Öğrencilerinin Sınav Kaygısı ile Boyuneğicilik Düzeyleri ve Sosyal Destek AlgıSı Arasındaki İlişkiler. Atatürk Üniversitesi Sosyal Bilimler Enstitüsü, 7 (1), 153-164.

Güler, D. ve Çakır. G. (2013). Lise Son Sınıf Öğrencilerinin Sınav Kaygısını Yordayan Değişkenlerin İncelenmesi. Türk Psikolojik Danışa ve Rehberlik Dergisi,4 (29), 82-94.

Gülüm, I. V. ve Dağ, İ. (2012). Tekrarlayıcı Düşünme Ölçeği ve Bilişsel Esneklik Envanterinin Türkçeye Uyarlanması, Geçerliliği Ve Güvenilirliği. Anadolu Psikiyatri Dergisi, 13 (3), 216-223.

Gürbüz, K. E. (2017). Pedagojik Formasyon Programı Öğrencilerinin Bilişsel Esneklik ve Öz Yeterlik Düzeyleri. Yayımlanmamış Yüksek Lisans Tezi. Bolu: Abant İzzet Baysal.

Hanımoğlu, E. (2010). Seviye Belirleme Sinavina Girecek Olan İlköğretim İkinci Kademe Öğrencilerinde Sinav Kaygısı, Mükemmeliyetçilik ve Anne-Baba Tutumu Arasındaki İlişkinin İncelenmesi. Yayımlanmamış Yüksek Lisans Tezi. Adana: Çukurova Üniversitesi, Sosyal Bilimler Enstitüsü.

Karaca, E. Yurdabakan, İ, Çetin, B. , Nartgün, Z. ve Gömleksiz, M. (2010). Ĕ̆itimde Ölçme ve Değerlendirme. Ankara, Nobel Yayıncilik.

Kardeş, A.G. (2016). Davranış-Mekân Uyumu: Bilişsel Esneklik Düzeyleri Farklı Öğrencilere Göre, Okul Ortamında Olanakllikların (Affordances) İncelenmesi. Yayımlanmamış Yüksek Lisans Tezi. Ankara: Ankara Üniversitesi. Eğitim Bilimleri Enstitüsü.

Kilit, Z. (2019). Üniversite Öğrencilerinde Belirsizliğe Tahammülsüzlük, Endişe ve Bilişssel Sınav Kaygısı İlişkisi. Yayımlanmamış Yüksek Lisans Tezi. İstanbul: Üsküdar Ünivesitesi, Sosyal Bilimler Enstitüsü.

Kurt, A. A. (2019). Genç Yetişkinlerde Akılcı Olmayan Romantik İlişki İnançları, Bilişsel Esneklik ve Benliğin Ayrımlaşması İlişkisinin İncelenmesi. Yayımlanmamış Yüksek Lisans Tezi. Mersin: Mersin Üniversitesi, Eğitim Bilimleri Enstitüsü. 
Kurt, E. Ö. (2017). Ortaokul Öğrencilerinin Sosyal Destek Algilarıyla İlgili Olarak Sinav Kaygısı ve Umutsuzluk Düzeylerinin İncelenmesi. Yayımlanmamış Yüksek Lisans Tezi. İstanbul: Beykent Üniversitesi, Sosyal Bilimler Enstitüsü.

Kurt, İ. (2006). Sorularla Kaygı ve Sinav Kaygısı. 2.Baskı. Ankara, Asil Yayın Dağıtım.

Lakot, H. (2019). 8. Sınıf Öğrencilerinin Sınav Kaygısı ile Fiziksel Aktivite Düzeyleri ve Beden Eğitimine İlişkin Yatkınlıklarının İncelenmesi. Yayımlanmamış Yüksek Lisans Tezi. Trabzon: Trabzon Üniversitesi, Lisansüstü Eğitim Enstitüsü.

Mohammadyari, G. (2012). Comparative study of relationship between general perceived self-efficacy and test anxiety with academic achievement of male and female students, Procedia-Social and Behavioral Sciences, $69,2119-2123$.

Onuk, T. (2017). Ergenlerde Kişilik Özelliklerinin Sınav Kaygısı ve Okula Bă̆lanma Stilleri Üzerinde Etkisi. Yayımlanmamış Yüksek Lisans Tezi. İstanbul: Işık Üniversitesi, Sosyal Bilimler Enstitüsü.

Oral, S. ve Kolburan, Ş. G. (2019). Çekişmeli Boşanma Sürecindeki Bireylerin Empatik Eğilim Düzeyleri ve Bilişsel Esneklik Düzeylerinin Bazı Değiş̧kenlere göre İncelenmesi. Yaşam Becerileri Psikoloji Dergisi, 3(6), 165-178. DOI: 10.31461/ybpd.607300.

Özcan, A. D. (2016). Ergenlerde Bilişsel Esneklik ile Özyeterlik Arasındaki İlişkinin İncelenmesi. Yayımlanmamış Yüksek Lisans Tezi. Mersin: Toros Üniversitesi, Sosyal Bilimler Enstitüsü.

Pazarlı, S. (2009). Öğrenme Stilleri ile Sınav Kaygısı Arasındaki İlişki (İstanbul İli Anadolu Yakası Örneği).Yayımlanmamış Yüksek Lisans Tezi. İstanbul: Yeditepe Üniversitesi, Sosyal Bilimler Entitüsü.

Putwain, D. W. (2007). Test Anxiety in UK Schoolchildren: Prevalence and Demographic Patterns. British Journal of Educational Psychology, 77(3), 579-593.

Semerci, B. ve Özer, A. S. (2007). Sınav Stresi ve Başa Çıkma Yolları. İstanbul, Merkez Kitapçlık Yayıncılık.

Serim, S. (2016). Sınav Kaygııs ile Geleceğe Yönelik Umut Beklentisi Arasındaki İlişki: 17-18 Yaş Arası İstanbul Lise Son Sımıf Öğrencileri Üzerine Bir Araştırma. Yayımlanmamış Yüksek Lisans Tezi. İstanbul: Beykent Üniversitesi, Sosyal Bilimler Enstitüsü.

Sinnott, J. , Hilton, S. , Wood, M. and Douglas, D. (2020). Relating Flow, Mindfulness, Cognitive Flexibility, and Postformal Thought: Two Studies. Journal of Adult Development, 27,1-11. DOI: https://doi.org/10.1007/s10804-018-9320-2.

Softa, H. K. , Karaahmetoğlu, G. U. ve Çabuk, F. (2015). Lise Son Sınıf Öğrencilerinin Sınav Kaygısı ve Etkileyen Faktörlerin İncelenmesi. Kastamonu Ĕ̆itim Dergisi, 23(4), 1481-1494.

Şahinler, G. (2018). On İkinci Sını Lise Öğrencilerinin Mesleki Olgunlukve Umut Düzeyi ile Sınav Kaygısı Arasındaki İlişkinin İncelenmesi. Yayımlanmamış Yüksek Lisans Tezi. Trabzon: Karadeniz Teknik Üniversitesi, Eğitim Bilimleri Enstisüsü.

Tutuş, A. (2019). 11-14 Yaş Arasında Olan Ergenlerin Stresle Başa Çıkma Tarzları ve Bilişsel Esneklik Düzeyleri Arasındaki İlişkinin Araştırılması. Yayımlanmamış Yüksek Lisans Tezi. Mersin: Çağ Üniversitesi, Sosyal Bilimler Enstitüsü.

Uluşahin, A. ve Öztürk, M. O. (2014). Ruh Sağlı̆̆ı ve Bozuklukları 1. 12. Baskı, Ankara, Nobel Tıp Kitapevi Yayınevi. 
Ün, M. D. (2018). Üniversite Sinavına Hazırlanan Öğrencilerde Sınav Kaygısı, Mükemmeliyetçilik ve Anne Baba Tutumu Arasındaki İlişkinin İncelenmesi. Yayımlanmamış Yüksek Lisans Tezi. İstanbul: Üsküdar Üniversitesi, Sosyal Bilimler Enstitüsü.

Ürgüp, B. (2017). Ebeveynle Gerçekleştirilen Bağlanma Stilinin Sınav Kaygısı Üzerindeki Yordayııı Etkisi. Yayımlanmamış Yüksek Lisans Tezi. İstanbul: Üsküdar Üniversitesi, Sosyal Bilimler Enstitüsü.

Yalçınkaya, N. (2011). İlköğretim 8. Sınıf Öğrencilerinin Türkçe Dersine Yönelik Tutumları ile Sınav Kaygısı Düzeyleri Arasındaki İlişkinin İncelenmesi. Yayımlanmamış Yüksek Lisans Tezi. Niğde: Niğde Üniversitesi, Sosyal Bilimler Enstitüsü.

Yavuz, S. (2019). Bedensel Engelli Sporcuların Psikolojik Sağlamlı ve Bilişsel Esneklik Düzeylerinin İncelenmesi. Yayımlanmamış Yüksek Lisans Tezi. Aksaray: Aksaray Üniversitesi, Sosyal Bilimler Enstitüsü.

Yolcu, M. A. (2014). Aile Sosyo-Ekonomik Durumu ve Anne-Baba Tutumlarmın Sinav Kaygısı Düzeyleri Üzerine Etkilerinin İncelenmesi (Konya Örneğinde Üniversite Sınavına Dershaneye Giderek Hazırlanan Öğrencilere Bir Uygulama).Yayımlanmamış Yüksek Lisans Tezi. Konya: Selçuk Üniversitesi, Sosyal Bilimler Enstitüsü.

Yusefzadeh, H., Iranagh, J. A., and Nabilou, B. (2019). The Effect of Study Preparation on Test Anxiety and Performance: A Quasi-Experimental Study. Advances in Medical Education and Practice, 10, 245.

Zahal, O. (2014). Özel Yetenek Sınavına Giren Adayların Öğrenme Stilleri ve Bilişsel Esneklik Düzeyleri ile Sınav Başarıları Arasındaki İlişki. Yayımlanmamış Doktora Tezi. Malatya: İnönü Üniversitesi, Eğitim Bilimleri Enstitüsü. 